\title{
Sotos Syndrome
}

National Cancer Institute

\section{Source}

National Cancer Institute. Sotos Syndrome. NCI Thesaurus. Code C75019.

An autosomal dominant overg rowth syndrome caused by mutation(s) of the NSD1 or the NFIX gene, encoding H3 lysine- 36 and H4 lysine-20 specific histone-lysine Nmethyltransferase, and nuclear factor $1 \mathrm{X}$-type, respectively. The condition is characterized by a disproportionately large and long head with a slightly prominent forehead and pointed chin, hypertelorism, down-slanting eyes, large hands and feet, overg rowth in childhood, and developmental delay. 